\title{
THE BRITISH AND SOUTH AFRICAN APPROACHES TO ASYLUM BASED ON SEXUAL ORIENTATION AND GENDER IDENTITY
}

\author{
As abordagens britânica e sul africana ao refúgio por motivos \\ de orientação sexual e identidade de gênero
}

Vítor Lopes Andrade*

\begin{abstract}
Since the 1980's it has been possible to claim asylum on the basis of sexual orientation and gender identity in some countries. Most studies on this topic focus on countries in the Global North. Therefore, there is still a lack of research that comparatively analyses the Global North with the Global South. The aim of this article is then to analyse and compare the approaches of two countries that grant refugee status on the basis of sexuality and gender identity, one in the Global North (the United Kingdom) and one in the Global South (South Africa).
\end{abstract}

Keywords: asylum; United Kingdom; South Africa; sexual orientation; gender identity.

Resumo. Desde a década de 1980, é possível solicitar refúgio por motivos de orientação sexual e identidade de gênero em alguns países. A maioria dos estudos sobre essa temática foca em países do Norte Global. Assim sendo, ainda há uma falta de pesquisas que analisem comparativamente o Norte Global com o Sul Global. O objetivo deste artigo é, portanto, analisar e comparar as abordagens de dois países que reconhecem o status de refugiado por motivos de sexualidade e identidade de gênero, um do Norte Global (Reino Unido) e outro do Sul Global (África do Sul).

Palavras-chave: refúgio; Reino Unido; África do Sul; orientação sexual; identidade de gênero.

\footnotetext{
Doctoral researcher in Social Anthropology in the School of Global Studies, University of Sussex.
} Brighton, United Kingdom. E-mail: V.Andrade@sussex.ac.uk. Orcid: 0000-0003-2750-0876. 


\section{Introduction ${ }^{1}$}

The category 'refugee' was created by the United Nations (UN) after the Second World War, when the United Nations High Commissioner for Refugees (UNHCR) was also created. According to the 1951 Refugee Convention ${ }^{2}$, the term would apply to any person who is not able to return to their country of origin owing to a well-founded fear of being persecuted on grounds of political opinion, race, religion, nationality or membership of a particular social group (Article 1A(2), Refugee Convention). Initially, the concept was developed having in mind only the events that resulted from the Second World War in Europe, but these geographical and temporal restrictions were abolished by the 1967 Protocol relating to the Status of Refugees ${ }^{3}$. Neither the Convention nor the Protocol defined the concept of 'Particular Social Group' (PSG). The meaning of 'well-founded fear of being persecuted' is also not precise. Therefore, PSG and 'well-founded fear of persecution' have been deeply debated in International Refugee Law (e.g., Grahl-Madsen, 1966; Goodwin-Gill, 1995; Hathaway, 2005).

In the 1980s and 1990s, when the first asylum applicants claimed refugee status on the basis of their sexual orientation, they used 'membership of a PSG' as the reason for (the fear of) persecution ${ }^{4}$. Thus, two questions were raised. First, did being gay/lesbian/bisexual qualify as membership of PSG under the 1951 Refugee Convention? This was related to the understanding of what characterises a PSG: is it an innate/immutable characteristic? Is it a common social identity? Does it depend on the persecutor's perception? Second, how might it be proved that each individual applicant had a 'well-founded fear of being persecuted' on the basis of their sexual orientation? Not surprisingly, then, legal scholars focused their attention on these topics.

Two of the pioneering scholars who since the mid-1990s extensively wrote on these issues were Nicole LaViolette (1996a, 1996b, 1997), in Canada, and Jenni Millbank $(1995,2002)$, in Australia. Due to the fact that refugee status for reasons of sexual orientation and gender identity (SOGI) was firstly claimed and granted in the Global North ${ }^{5}$, it is understandable that this

1 This study was financed in part by the Coordenação de Aperfeiçoamento de Pessoal de Nível Superior - Brasil (CAPES).

2 The Convention relating to the Status of Refugees (1951). Available at: <https://www.unhcr.org/ uk/3b66c2aa10>. Accessed: 22.04.2019.

3 The Protocol relating to the Status of Refugees (1967). Available at: <https://www.unhcr.org/ uk/3b66c2aa10>. Accessed: 22.04.2019.

4 Eventually, when refugee status based on gender identity was claimed, the reason for (the fear of) persecution was also 'membership of a PSG'.

5 The first case was in the Netherlands. Afdeling rechtspraak van de Raad van State (Judicial Division of the Council of State), 13 August 1981, Rechtspraak Vreemdelingenrecht 1981, 5 , Gids Vreemdelingenrecht (oud) D12-51. 
area of knowledge was primarily studied in these countries, especially in the English-speaking world, e.g., United States of America, Canada and Australia.

In the 2000s, more attention was given to asylum based on SOGI. In 2002, the UNCHR launched two Guidelines on International Protection, one about gender-related persecution (UNHCR, 2002a) and the other about membership of a PSG (UNHCR, 2002b). Both addressed SOGI claimants ${ }^{6}$. One of the reasons why SOGI have begun to be more debated in the realm of asylum was because Lesbian, Gay, Bisexual, Trans and Intersex (LGBTI) rights were being increasingly discussed internationally. In other words, the 'international LGBTI agenda' was growing at that time, advocating that LGBTI rights were Human Rights. In 2007, for example, a group of experts wrote the Yogyakarta Principles on the Application of International Human Rights Law in relation to Sexual Orientation and Gender Identity (2007). Principle 23 was on 'the right to seek asylum'.

In the following years, and especially from the 2010s, academic studies as well as reports from International Organisations and Non-Governmental Organisations (NGOs) on SOGl asylum started to be published in relation to other countries in the Global North, such as Portugal (Vieira, 2011; Ferreira, 2015) and Spain (Díaz Lafuente, 2013), and in the Global South, such as Brazil (Oliva, 2012) and South Africa (PASSOP, 2012; Okisai, 2015). In 2012, the UNHCR published a Guideline on International Protection specifically addressing SOGI asylum claims (UNHCR, 2012). One year before, Jansen and Spijkerboer (2011) had published the report 'Fleeing Homophobia', which is a comprehensive comparative study focusing on the main issues concerning the RSD process in European Union (EU) Member States. This report has had a great influence on researchers working on SOGI asylum in Europe and beyond. A few other comparative works had been published before (e.g., Millbank, 2002) and after Jansen and Spijkerboer's report (e.g., ILGA-EUROPE, 2014) focusing on different countries in the Global North. There is still a lack of research that comparatively analyses the Global North with the Global South ${ }^{7}$.

Such a comparison is important in order to question the uncritical view that the North receives refugees and is a 'safe haven' to SOGI asylum claimants and refugees, while the South only 'exports' refugees and does not guarantee any kind of rights regarding SOGI. Having said that, the purpose of this article

6 The acronym "SOGI" was not used at that time yet. These documents refer to "homosexuals", "transsexuals" and "transvestites".

7 I have recently made an attempt to analyse and compare asylum based on sexual orientation from a North-South perspective relying on my previous research in Brazil and Spain (Andrade, 2018). McNeal (2019) has published an interesting article in which he adopts a North-South perspective; however, instead of comparing two countries that grant refugee status based on sexual orientation, his analysis is about SOGI refugees from one country of origin in the Global South (Trinidad and Tobago) to one country of destination in the Global North (United Kingdom). 
is to analyse and compare the approaches of two countries that grant refugee status on the basis of SOGI, one in the Global North and one in the Global South. It is important to mention that this is part of a broader research project whose aim is to analyse not only the legal process of being granted refugee status, but also the social experiences of SOGl asylum claimants and refugees ${ }^{8}$. This is, therefore, a work in progress. To write this specific article, I have relied on different sources, such as journal articles, PhD theses, and NGO reports.

In order to conduct this North-South analysis, I have chosen to study the United Kingdom (UK) and South Africa (SA). During the last few years, the UK has been one of the five EU Member States with the highest number of asylum applicants (EUROSTAT, 2020). Although these five countries grant refugee status on the basis of sexual orientation, the UK is the only one that has official statistics. According to the Home Office ${ }^{9}$ (2018), 5,916 claims based on sexual orientation were made from 2015 to 2017, most of them by nationals from Pakistan, Bangladesh, Nigeria, Uganda and Iran. The UK has been a desirable destination for SOGI asylum claimants in the Global North, not only due to the image of 'sexual freedom' associated with the country, but also because of the linguistic and cultural ties with the claimants' countries of origin, which are mostly former British colonies.

According to the UNHCR (2018, p. 41), SA was the main country of destination for asylum applicants until 2011/2012. In 2017, SA was amongst the sixteen main countries of destination in the world and the three ones in Africa (UNHCR, 2018, p. 41) ${ }^{10}$. It holds one of the most progressive refugee legislations in the world, in which PSG is defined including gender and sexual orientation. Yet there are no official data on SOGI asylum claimants and refugees. Since the South African Constitution and refugee legislation are very progressive regarding SOGl rights, the country has also an image of 'sexual freedom' and is the most realistic place for people claiming asylum based on SOGl in Africa.

Therefore, the UK and SA are key destinations for these claimants in the North and South respectively. Both countries started considering SOGI as a characteristic that contribute to the constitution of a PSG, consequently granting refugee status to claimants on this ground, in the late 1990s. However, the way in which these countries achieved this understanding was different.

8 This broader project is my doctoral research. It has been conducted in the School of Global Studies at the University of Sussex.

9 The Home Office is the British government department for immigration, as well as drug policy, crime, fire, police and counter-terrorism. See <https://www.gov.uk/government/organisations/ home-office/about>.

${ }^{10}$ In Africa, Uganda was the main country of asylum, followed by the United Republic of Tanzania and South Africa (UNHCR, 2018, p. 41). 


\section{The United Kingdom}

In comparison to other countries in the Global North, the UK was reluctant to consider SOGI as a factor potentially leading to the finding of a PSG (Millbank, 2005; Arnold, 2012). While the Netherlands, for example, first accepted this understanding in $1981^{11}$, it was only in 1999 - after a judgment in the UK House of Lords (now Supreme Court) - that this started to be possible in the UK. In the joint appeal of Shah and Islam ${ }^{12}$, the question was whether or not two Pakistani women were members of a PSG according to article $1 \mathrm{~A}(2)$ of the Refugee Convention. The women were forced by their husbands to leave their homes, being falsely accused of adultery. The case was therefore related to gender, not specifically to sexual orientation. However, during the judgment it was concluded that individuals fearing persecution based on gender, linguistic background, and sexual orientation could be understood as PSG.

From 1999 onwards, it has thus been possible to claim asylum based on SOGI in the UK. Nevertheless, according to a report from the UK Lesbian and Gay Immigration Group (UKLGIG) $)^{13}$, gaining asylum on this ground was very unlikely: $98-99 \%$ of the claims were rejected at the initial stage (UKLGIG, 2010 , p. 2) ${ }^{14}$. Until 2010, the most common reason to deny asylum to SOGI claimants was the 'discretion' requirement: the reasoning was that SOGI asylum claimants could go back to their countries of origin and be 'discreet' about their sexual orientation, lying about their sexuality, not having a same-sex relationship, etc. In other words, they could conceal that they were not heterosexual, and so they would not be persecuted (Millbank, 2009, p. 393; UKLGIG, 2010, p. 4; Briddock, 2016, p. 128). According to Millbank (2009, p. 393), the discretion reasoning subverts the aim of the Refugee Convention: instead of the receiving state being responsible for providing international protection, the responsibility of protection is placed upon the applicant, who needs to avoid being persecuted. Furthermore, the discretion requirement is not applied to persons claiming asylum on other grounds, such as religion and political opinion (Millbank, 2009, p. 393; UKLGIG, 2010, p. 4; Briddock, 2016, p. 128).

\footnotetext{
11 Afdeling rechtspraak van de Raad van State (Judicial Division of the Council of State), 13 August 1981, Rechtspraak Vreemdelingenrecht 1981, 5, Gids Vreemdelingenrecht (oud) D12-51.

12 Islam (A.P.) v. Secretary of State for the Home Department Regina v. Immigration Appeal Tribunal and Another Ex Parte Shah (A.P.) (Conjoined Appeals). Available at: < https://publications. parliament.uk/pa/ld199899//djudgmt/jd990325/islam01.htm > . Accessed: 11.03.2019.

13 UKLGIG was founded in 1993 and since 2003 has been offering support services and legal advice to SOGI asylum claimants and refugees in the UK. See: <https://uklgig.org.uk/>.

${ }^{14}$ The average refusal rate in the same period for other claims was 73\% (UKLGIG, 2010, p. 2).
} 
It was only in 2010 that this reason to deny asylum became less tolerable and common in the UK. In HJ (Iran) and HT (Cameroon) ${ }^{15}$, the UK Supreme Court judged the cases of two gay asylum claimants. Both applications had been previously unsuccessful due to the discretion requirement. The UK Supreme Court considered that this requirement was incompatible with the purposes of the Refugee Convention. This judgment was therefore an important advancement concerning SOGI asylum in the UK, since it was no longer possible to deny asylum merely alleging that claimants would not be at risk of persecution if they returned to their countries of origin and concealed their sexual orientation. However, this judgment did not end the use of the discretion requirement completely (Weßels, 2013) ${ }^{16}$.

According to UKLGIG (2013), despite some improvement in the quality of initial decisions on SOGI asylum applications as a consequence of the Supreme Court's 2010 decision, what happened was a change in the reasoning to refuse asylum. Since 2011, the great majority of SOGI claims have been denied because decision makers do not believe the claimant to be gay, lesbian or bisexual (UKLGIG, 2013, p. 12). Different authors show that the Home Office and the tribunals look for (Western) stereotypes during the credibility assessment for SOGI claimants. Giametta $(2017$, p. 1) identifies that applicants need to reconstruct themselves as archetypal asylum claimants, fitting their narratives into what the decision makers want to hear. In this process, gender must be performed in a specific way if the applicant wants to be considered a 'real' lesbian or gay (Giametta, 2017, p. 2). Briddock notes that there is 'an expectation that once an LGBTI+ person finds their way to a country where there is no SOGI persecution, the person should immediately be out and proud and marching around with a rainbow flag' (Briddock, 2016, p. 140). Held (2015) examines further this idea of being 'out and proud'. According to the author, for an asylum claim to be successful in the UK, the applicant must conform to this racialised Western model of sexuality that represents a stereotypical white, male, middle-class gay identity. This understanding of

${ }^{15}$ HJ (Iran) and HT (Cameroon) v Secretary of State for the Home Department [2010] UKSC 31. Available at: <https://www.supremecourt.uk/decided-cases/docs/UKSC_2009_0054_Judgment. pdf $>$. Accessed: 11.03.2019.

16 The judgment created a new 'test' in relation to sexuality-based asylum claims according to decision makers' perception on whether or not applicants would conceal their sexual orientation. If they would not conceal, they would therefore be at risk of persecution and then have a well-founded fear of being persecuted. If the decision makers find that applicants would conceal their sexual orientation, two situations are possible: if the reason to conceal is due to a well-founded fear of persecution, they should be granted international protection; however, if the reason is due to 'social or family pressures', they are not at real risk of persecution and should not be granted asylum. This test therefore still allows to deny asylum in some cases, depending on the hypothesis created by decision-makers: it is very difficult to know, and to distinguish, the reason(s) why applicants would conceal their sexual orientation if returned to their countries of origin (see Weßels, 2013). 
sexuality includes having a relationship and adopting a gay lifestyle, that is, going to gay venues, participating in Gay Prides, etc (Held, 2015, p. 144).

Currently, what mostly defines the Home Office approach to SOGI asylum claims is this general culture of disbelief ${ }^{17}$. The same evidence may be used to produce favourable or unfavourable decisions, depending on the decision maker, which constitutes a 'Catch-22 situation' (UKLGIG, 2013, p. 14). For example, it is expected that claimants will mention going to LGBTI+ bars and clubs as proof of being really gay or lesbian; however, this might also be considered a reason to doubt the claimant's credibility through the logic that if asylum claimants do not work, they do not have enough money to go to nightclubs (UKLGIG, 2013, p. 14). The applicants' own testimony on their sexualities are commonly not enough (Briddock, 2016, p. 151). One of the consequences is that applicants have found themselves in a situation where they felt they had to produce sexually explicit material of themselves in order to try to 'prove' their sexual orientation (Lewis, 2014). The most recent report from UKLGIG (2018) points out that there has been a significant improvement in Home Office practice regarding sexually explicit evidence - especially because of the 'Asylum Policy Instruction: sexual orientation in asylum claims' (Home Office, 2015, 2016) (18 $^{18}$, but the high standard of proof imposed on SOGI claimants is still problematic.

The overall analysis of the British approach to SOGI asylum claims is that despite some improvement over the last years ${ }^{19}$, decision makers have been consistently looking for reasons to deny refugee status. The reasoning has been changing and it is possible to trace three periods (Dustin, 2018). First, before 1999, asylum was not granted to SOGI claimants in the UK because SOGI was not even considered a factor relevant to finding a PSG according to the Refugee Convention. Second, from 1999 to 2010, the most usual reasoning to deny asylum was the assumption of the lack of well-founded fear of being persecuted, since claimants could return to their countries of origin and be 'discreet'. Finally, the most common reasoning in order to avoid granting asylum to SOGI claimants currently concerns lack of credibility, that is, the assumption that claimants are not really gay, lesbian or bisexual ${ }^{20}$.

${ }^{17}$ It is relevant to note that this culture of disbelief characterises the Home Office approach to asylum claims generally. See, for instance, Kea and Roberts-Holmes (2013, p. 100-101).

${ }^{18}$ The purpose of this Home Office document is to explain how caseworkers should consider claims based on sexual orientation.

19 This improvement has been influenced by judgments of British courts, as well as of other European jurisdictions (such as the European Court of Human Rights and the Court of Justice of the EU), and also because of the different tools that constitute the Common European Asylum System. For a discussion of SOGI asylum in these different European levels, see Ferreira (2018).

${ }^{20}$ It is important to note that the number of claims based on sexual orientation is much higher than the ones based on gender identity. There is thus more information available in relation to claimants identified as gay, lesbian or bisexual, compared to the ones identified as transgender. 


\section{South Africa}

South Africa had a different path towards the recognition of SOGI as a relevant factor to determine the existence of a PSG. In order to address this, it is necessary to briefly mention some aspects of South African recent history. From 1948 to the early 1990s, the country lived under Apartheid, an institutionalised system of racial segregation. Cronjé, one of the most important racist ideologues of this regime, maintained that miscegenation was a crime against the white 'race' (i.e., descendants of Dutch and British colonisers); therefore, they needed to be protected (Moutinho, 2010, p. 244). In order to do so, some laws to avoid miscegenation came into force, such as the Prohibition of Mixed Marriages Act in 1949, followed by the Immorality Amendment Act in 1950, which declared illegal sex between people from different 'races'. The segregation concerned not only marriage and sex, but also places where each 'race' could be or not (Bhagat, 2018). In this sense, cities were geographically divided into areas where 'whites', on the one hand, and 'blacks' or 'coloureds', on the other hand, could live. If a 'black' person happened to be in a 'white' place after the legally prescribed time, the person could be arrested (Leap, 2002, p. 226). It was just in the 1990s that institutionalised Apartheid ended in South Africa.

During the democratisation process in the 1990s, it was crucial to repair the injustices perpetrated by the segregation system. This was the context in which the Constitution of the Republic of South Africa was devised and written, and then adopted in $1996^{21}$. This Constitution is considered one of the most progressive in the world. Particularly interesting is the Equality Clause of the Bill of Rights (Chapter 2, Section 9, Part 3), in which it is declared that the state may not discriminate against anyone on the grounds of 'race, gender, sex, pregnancy, marital status, ethnic or social origin, colour, sexual orientation, age, disability, religion, conscience, belief, culture, language and birth'. In doing so, the South African Constitution became the first one in the world to explicitly prohibit discrimination on the basis of sexual orientation (Moodley, 2012; ORAM, 2013; Okisai, 2015; Kremin, 2017). The idea was that SA would become a 'rainbow nation', that is, a nation 'united in our diversity' (Preamble, The Constitution of the Republic of South Africa, 1996).

The Refugee Act 130 of $1998^{22}$ followed this new legal standard of equality and justice. 'Refugee' was defined in accordance with the 1951 Refugee Convention and the 1967 Protocol, and incorporated the definition of the 1969 Organization of African Unity's Convention Governing the Specific

\footnotetext{
${ }^{21}$ The Constitution of the Republic of South Africa (1996). Available at: <http://www.justice.gov. za/legislation/constitution/SAConstitution-web-eng.pdf > . Accessed: 13.03.2019.

${ }^{22}$ Republic of South Africa. The Refugee Act 130 (1998). Available at: <https://www.refworld.org/ docid/4a54bbd4d.html>. Accessed: 13.03.2019.
} 
Aspects of Refugee Problems in Africa (OUA Convention) ${ }^{23}$. This Convention expanded the definition of refugee, including persons who are compelled to leave their countries because of 'external aggression, occupation, foreign domination or events seriously disturbing or disrupting public order' (OUA Convention, Article 1, Section 2). This definition allows persons who are not specifically persecuted as individuals to ask for asylum when fleeing generalised violence (Harris, 2009, p. 297), that is, it lowers the burden of proof required to claim asylum (Kremin, 2017, p. 7), which can be important for SOGI claimants. Furthermore, the South African Refugee Act defines 'social group', declaring that it 'includes, among others, a group of persons of particular gender, sexual orientation, disability, class or caste' (Chapter 1, Article 1, Section xxi). The Act was considered one of the best pieces of refugee legislation in the world (Harris, 2009, p. 293; Kremin, 2017, p. 9); however, in January 2020 the Refugee Amendment $\mathrm{Act}^{24}$ and Refugee Regulations ${ }^{25}$ came into force, making fundamental changes in the Refugee $\mathrm{Act}^{26}$.

The fact that the Constitution prohibits discrimination based on sexual orientation and that the Refugee Act explicitly indicates SOGl as a reason to claim asylum are noteworthy in the African context, where there is the widespread idea that homosexuality is unAfrican, and an importation from the Global North (Haskins, 2014, p. 400; Camminga, 2016, p. 133). The progressive legislation turned SA into the most realistic place for people seeking asylum on the basis of SOGI in Africa. However, homophobia and xenophobia are widespread in South African society (Roberts, Reddy, 2008, p. 10; ORAM, 2013, p. 6-7; Beetar, 2017, p. 135; Kremin, 2017, p. 65). The changes in the legislation did not transform the social realities of discrimination faced by people in the country. Additionally, the legislation has not been applied properly. In the case of asylum claimants and refugees, the South African Department of Home Affairs (DHA) ${ }^{27}$ has been extremely criticised (Harris, 2009; Amit, 2012; Moodley, 2012; ORAM, 2013; Okisai, 2015; Kremin, 2017).

${ }^{23}$ The OUA Convention Governing the Specific Aspects of Refugee Problems in Africa (1969). Available at: <https://www.unhcr.org/about-us/background/45dc1a682/oau-conventiongoverning-specific-aspects-refugee-problems-africa-adopted.html>. Accessed: 13.03.2019.

24 Republic of South Africa. Act No. 11 of 2017: Refugee Amendment Act, 2017. Available at: $<$ https://scalabrini.org.za/wp-content/uploads/2020/01/Refugee_Amendment_Act_2017.pdf>. Accessed: 14.04.2020.

${ }^{25}$ Republic of South Africa. Refugee Regulations on the Refugees Act, 1998 (Act No. 130 of 1998). 27 December 2019. Available at: <https://scalabrini.org.za/wp-content/uploads/2020/01/ Regulations-Refugee-Amendment-Act-2018.pdf>. Accessed: 14.04.2020.

26 These changes affect the asylum application process, the appealing system, the right to work and study, expand the reasons under which a refugee status can be withdrawn, etc. In short, they make it harder to be granted refugee status and easier to lose it, apart from limiting the rights of asylum claimants and refugees in South Africa.

27 The Department of Home Affairs (DHA) is the South African government department for immigration, as well as for civic services, such as travel and identity documents and birth, marriage and death records. See <http://www.dha.gov.za/index.php/about-us>. 
One of the problems faced by asylum claimants is the difficulty to access the asylum system (Harris, 2009, p. 301). Finding a Refugee Reception Office (RRO) to apply for asylum or renew documents is the first obstacle, because they are constantly changing their addresses (Camminga, 2016, p. 145). The queues to enter the RROs are long and sometimes it is necessary to wait for days (ORAM, 2013, p. 5; Camminga, 2016, p. 146). Different authors show that corruption is widespread within the DHA and permeates all stages of the asylum process (Okisai, 2015, p. 49), characterising a 'culture of corruption' (Kremin, 2017, p. 40-41) in which claimants who are able to bribe authorities are more likely to access the asylum system and to be granted refugee status (ORAM, 2013, p. 1; Okisai, 2015, p. 30-31; Camminga, 2016, p. 152-153). Discrimination, harassment and mistreatment based on xenophobia and homo/ transphobia are reported to be perpetrated by the police, asylum authorities and government officials (Harris, 2009, p. 302; ORAM, 2013, p. 1). Extensive delay in the processing times, which may last for years, is another problem faced by asylum claimants in SA (Harris, 2009, p. 301; Okisai, 2015, p. 36).

The refugee status determination decisions produced by the DHA use arbitrary or irrelevant reasoning (ORAM, 2013, p. 6) and are commonly based on careless cutting and pasting from one decision to another (Amit, 2012, p. 99; ORAM, 2013, p. 6). According to Okisai (2015, p. 22), most of the SOGI asylum claims are denied based on the lack of a well-founded fear of persecution. The DHA argues that the asylum claimants could internally relocate within their own countries in order to avoid persecution, even when these countries criminalise homosexuality, which is the case of Tanzania and Nigeria, for instance. Apparently, the lack of a well-founded fear of persecution is the most usual reason used to deny SOGI asylum claims not only by the DHA, but also by the SA Refugee Appeal Board (RAB).

In 2002, the RAB judged the case of a gay Nigerian appellant ${ }^{28}$. He was arrested in Lagos in 1998 on account of his sexual orientation. After paying a bribe to the police, he was released from custody and then decided to flee to South Africa. Credibility assessment was not an issue, since the RAB considered the appellant as being a 'homosexual person'. However, the question of whether a homosexual would fall within the category of membership of a PSG according to the Refugee Act was raised in the decision. The conclusion - relying on some international judgments, such as Shah and Islam - was affirmative. Yet, this question was unnecessary because, as mentioned before, social group is defined in the South African Refugee Act including sexual orientation. This therefore shows a lack of knowledge regarding the legislation by decision

${ }^{28}$ Refugee Appeal Board Decision (Nigeria), South Africa: Refugee Appeal Board, 13 May 2002. Available at: <https://www.refworld.org/cases,SA_RAB,4b0e98fc2.html>. Accessed: 13.03.2019. 
makers. Although the appellant had been arrested because homosexuality is criminalised in Nigeria, the RAB found that in Nigeria authorities do not actively seek out homosexuals and that the risk of prosecution for homosexuality is minimal, as long as the homosexual activities are carried out discreetly'29. The appeal was then dismissed on account of a lack of well-founded fear of being persecuted and the RAB recommended that 'the appellant should apply a certain degree of discretion which required that the appellant avoid overt and public $[\ldots]$ homosexual activity $[\ldots]^{\prime 30}$. In another decision, made in 2011 and involving a gay Tanzanian appellant ${ }^{31}$, the conclusion was very similar. His sexual orientation was accepted as credible by the RAB. Although homosexuality is criminalised in Tanzania and the appellant faced familial and community harassment because of his sexual orientation, the appeal was dismissed due to a lack of well-founded fear of being persecuted.

The overall analysis of the situation in SA is that, on the one hand, both the Constitution and the Refugee Act are progressive and guarantee rights concerning SOGI. On the other hand, to access these rights in reality is much more complicated. In general, the DHA operates through an anti-asylum claimants bias (Amit, 2012, p. 10), rejecting the greatest number of claims due to the belief that applicants are economic migrants who do not need international protection (Kremin, 2017, p. 58). In relation to the SOGI asylum claims, the most common reason for rejection has been the lack of a well-founded fear of being persecuted, relying on the idea that asylum claimants can go back to their countries and live 'discreetly'. Therefore, the DHA and the RAB have been using the same reasoning that was mostly used by British decision makers until 2010.

\section{Conclusion}

Neither the 1951 Refugee Convention, nor the 1967 Protocol mentioned $\mathrm{SOGl}$ as a reason to be granted refugee status. However, since the 1980 s some countries have started considering SOGI as a 'membership of a PSG'. It firstly happened in countries of the Global North, which explains why this type of refuge was mostly studied in those countries. Later, refugee status based on SOGI has also started to be granted in the Global South. Yet there is still a lack of comparative studies between the Global North and the Global South. This kind of comparison is relevant in order to question the idea that the North is a 'safe haven' for SOGl asylum claimants and refugees, while the South only 'produces' refugees and does not guarantee any right in relation to SOGI.

\footnotetext{
29 Ibidem, p. 37.

30 Ibidem, p. 38.

31 Refugee Appeal Board Decision (Tanzania), South Africa: Refugee Appeal Board, 5 December 2011. Available at: <https://www.refworld.org/docid/5034f59a2.html>. Accessed: 13.03.2019.
} 
Regarding the two countries analysed in this paper, while the UK was reluctant to consider SOGI as a factor relevant to determine belonging to a PSG and to grant asylum on this basis compared to other countries in the Global North, SA was very progressive - particularly, but not only in the Global South - regarding the recognition of SOGI rights to nationals and asylum claimants. In both countries, claiming asylum based on SOGI has been possible since the late 1990s. What the discussion above shows, however, is that both governments have been developing and applying strategies in order to deny asylum to SOGI claimants. These strategies range from the difficulty in finding RROs to changes in the reasoning to deny refugee status. It seems that in the UK these strategies are more orchestrated and shift from time to time, while in SA different strategies overlap in a more disorganised way. It is important to note, however, that the 'disorganisation' of the asylum system can be analysed as an efficient state strategy in order to make it more difficult to claim asylum ${ }^{32}$.

This paper focused on some legal aspects of SOGI asylum, particularly the understanding of SOGI as membership of a PSG in the UK and SA. As mentioned before, it is part of a broader research project. The next step, therefore, is to analyse and compare the everyday life experiences of asylum claimants and refugees in these two countries, that is, to find out which strategies they develop and use in navigating the asylum system.

\section{References}

AMIT, Roni. All road lead to rejection: persistent bias and incapacity in South African refugee status determination. ACMS Research Report. 2012. Available at: $<$ http://www.migration.org.za/wp-content/uploads/2017/08/All-Roads-Leadto-Rejection-Persistent-Bias-and-Incapacity-in-South-African-Refugee-StatusDetermination.pdf $>$. Accessed: 14.04.2020.

ARNOLD, Samantha. Nexus with a convention ground: the particular social group and sexual minority refugees in Ireland and the United Kingdom. Irish Law Journal, v. 1, p. 93-119, 2012.

ANDRADE, Vítor Lopes. Refugee status determination and local integration of asylum seekers and refugees on the basis of sexual orientation in Brazil and Spain. Genius - Rivista di studi giuridici sull orientamento sessuale e l'identità di genere, v. V, n. 2, p. 88-103, 2018.

BEETAR, Matthew. Transcontinental lives: intersections of homophobia and xenophobia in South Africa (PhD thesis). Brighton: University of Sussex, 2017.

\footnotetext{
32 It is also important to note that strategies to deny asylum have been used towards asylum claimants in general, not only in relation to those who claim on the basis of SOGI. The focus here was on the specificities that affect the SOGI claims, but it is important to mention that these claims are also affected by restrictive migration policies in general, which are often based on nationalist and xenophobic movements.
} 
BHAGAT, Ali. Forced (Queer) migration and everyday violence: the geographies of life, death, and access in Cape Town. Geoforum, v. 89, p. 155-163, 2018.

BRIDDOCK, Allan. The recognition of refugees based on sexual orientation and gender identity in the UK: an overview of law and procedure. Birkbeck Law Review, v. 4, n. 1, p. 123-157, 2016.

CAMMINGA, B. Bodies over borders and borders over bodies: the 'gender refugee' and the imagined South Africa (PhD thesis). Cape Town: University of Cape Town, 2016.

DÍAZ LAFUENTE, José. Estudio de la doctrina jurisprudencial española sobre la protección internacional por motivos de orientación sexual e identidad de género. In: FABADO, Isabel (ed.). Libertad de circulación, asilo y refugio en la Unión Europea. Valencia: Tirant lo Blanch, 2013, p. 69-92.

DUSTIN, Moira. Many rivers to cross: the recognition of LGBTQI asylum in the UK. International Journal of Refugee Law, v. 30, n. 1, p. 104-127, 2018.

DUSTIN, Moira; HELD, Nina. In or out? A queer intersectional approach to "particular social group" membership and credibility in SOGl asylum claims in Germany and the UK. GenIUS - Rivista di studi giuridici sull'orientamento sessuale e sull'identita' di genere, v. 2, p. 74-87, 2018.

EUROSTAT. Asylum quarterly report. Statistics Explained. 2020. Available at: <https://ec.europa.eu/eurostat/statistics-explained/index.php/Asylum_quarterly_ report>. Accessed: 14.04.2020.

FERREIRA, Nuno. Portuguese Refugee Law in the European context: the case of sexuality-based claims. International Journal of Refugee Law, v. 27, n. 3, p. 411432, 2015.

FERREIRA, Nuno. Reforming the Common European Asylum System: enough rainbow for queer asylum seekers?. GenIUS - Rivista di studi giuridici sull'orientamento sessuale e sull'identita' di genere, v. 2, p. 25-42, 2018.

GIAMETTA, Calogero. The sexual politics of asylum: sexual orientation and gender identity in the UK asylum system. New York and London: Routledge, 2017.

GOODWIN-GILL, Guy. Refugee in International Law. 2nd ed. Oxford: Oxford University Press, 1995.

GRAHL-MADSEN, Atle. The status of refugees in International Law: Refugee Character. Volume I. Leyden: A. W. Sijthoff, 1966.

HARRIS, Lindsay. Untold stories: gender-related persecution and asylum in South Africa. Michigan Journal of Gender \& Law, v. 15, p. 291-347, 2009.

HASKINS, Susan. The influence of Roman laws regarding same-sex acts on homophobia in Africa. African Human Rights Law Journal, v. 14, p. 393-411, 2014.

HATHAWAY, James. The Rights of Refugees under International Law. Cambridge: Cambridge University Press, 2005.

HELD, Nina. What does a "genuine lesbian" look like? Intersections of sexuality and "race" in Manchester's Gay Village and in the UK asylum system. In: STELLA, 
Francesca et al. (eds.). Sexuality, citizenship and belonging: trans-national and intersectional perspectives. London: Routledge, 2015, p. 131-148.

HOME OFFICE. Asylum policy instruction: sexual identity issues in the asylum claim. 2015. Available at: < https://rm.coe.int/CoERMPublicCommonSearchServices/Dis playDCTMContent?documentld=0900001680488fd6>. Accessed: 15.04.2020.

HOME OFFICE. Asylum policy instruction: sexual orientation in asylum claims. 2016. Available at: <https://assets.publishing.service.gov.uk/government/ uploads/system/uploads/attachment_data/file/543882/Sexual-orientation-inasylum-claims-v6.pdf>. Accessed: 15.04.2020.

HOME OFFICE. Experimental statistics: asylum claims on the basis of sexual orientation. 2018. Available at: <https://www.gov.uk/government/publications/ immigration-statistics-year-ending-june-2019/experimental-statistics-asylumclaims-on-the-basis-of-sexual-orientation > . Accessed: 15.04.2020.

ILGA-EUROPE. Good practices related to LGBTI asylum applicants in Europe. 2014. Available at: <https:/www.ilga-europe.org/sites/default/files/good practices_related_to_Igbti_asylum_applicants_in_europe_jul14.pdf $>$. Accessed: 14.04.2019.

JANSEN, Sabine; SPIJKERBOER, Thomas. Fleeing homophobia: asylum claims related to sexual orientation and gender identity in Europe. Amsterdam: COC Nederland and Vrije Universiteit Amsterdam, 2011.

KEA, Pamela; ROBERTS-HOLMES, Guy. Producing victim identities: female genital mutilation and the politics of asylum claims in the United Kingdom. Identities, v. 20, n. 1, p. 96-113, 2013.

KREMIN, Marijke. To be out and in: influencing factors in the recognition of SOGIbased asylum claims in South Africa and Kenya. (Master's thesis). Nova York: Columbia University, 2017.

LAVIOLETTE, Nicole. Proving a well-founded fear: the evidentiary burden in refugee claims based on sexual orientation. In: LEVY, Sydney (ed.). Asylum based on sexual orientation: a resource guide. United States of America: The International Gay and Lesbian Human Rights Commission and LAMBDA Legal Defense and Education Fund, 1996a, p. 3-11.

LAVIOLETTE, Nicole. Sexual orientation and the refugee determination process: questioning a claimaint about their membership in the particular social group. In: LEVY, Sydney (ed.). Asylum based on sexual orientation: a resource guide. United States of America: The International Gay and Lesbian Human Rights Commission and LAMBDA Legal Defense and Education Fund, 1996b, p. 13-19.

LAVIOLETTE, Nicole. The immutable refugees: sexual orientation in Canada (A.G.) v. Ward. University of Toronto Faculty of Law Review, v. 55, n. 1, p. 1-41, 1997.

LEAP, William. "Strangers on a train": sexual citizenship and the politics of public transportation in Apartheid Cape Town. In: CRUZ-MALAVÉ, Arnaldo; MANALANSAN, Martin (eds.). Queer globalizations: citizenship and the afterlife of colonialism. New York and London: New York University Press, 2002. 
LEWIS, Rachel. "Gay? Prove it": the politics of queer anti-deportation activism. Sexualities, v. 17, n. 8, p. 958-975, 2014.

MCNEAL, Keith. Confessions of an ambivalent country expert: queer refugeeism in the UK and the political economy of (im)mobility in and out of Trinidad and Tobago. Anthropological Theory, v. 19, n. 1, p. 191-215, 2019.

MILLBANK, Jenni. Fear of persecution or just a queer feeling?. Alternative Law Journal, v. 20, n. 6, p. 261-265, 1995.

MILLBANK, Jenni. Imagining otherness: refugee claims on the basis of sexuality in Canada and Australia. Melbourne University Law Review, v. 26, p. 144-177, 2002.

MILLBANK, Jenni. A preoccupation with perversion: the British response to refugee claims on the basis of sexual orientation, 1989-2003. Social \& Legal Studies, v. 14, n. 1, p. 115-138, 2005.

MILLBANK, Jenni. From discretion to disbelief: recent trends in refugee determinations on the basis of sexual orientation in Australia and the United Kingdom. The International Journal of Human Rights, v. 13, n. 2-3, p. 391-414, 2009.

MOODLEY, Yellavarne. Receiving LGBTI refugees in South Africa: towards a culture of non-discrimination and Human Rights. Working Paper Series. University of Cape Town: Refugee Rights Unit. 2012. Available at: < http://www.refugeerights. uct.ac.za/usr/refugee/Working_papers/Working_Paper_5_of_2012.pdf > . Accessed: 15.04.2020.

MOUTINHO, Laura. A brief history of the research and its ideas. Sexuality Research and Social Policy, v. 7, p. 243-251, 2010.

OKISAI, Kizitos. Sexual orientation and gender identity asylum claims and refugee protection under South African Law. (Master's thesis). University of Pretoria, Pretoria, 2015.

OLIVA, Thiago. Minorias sexuais enquanto "grupo social" e o reconhecimento do status de refugiado no Brasil. 2012. Available at: <https://www.acnur.org/ fileadmin/Documentos/portugues/eventos/Minorias_Sexuais_enquanto_Grupo_ Social.pdf $>$. Accessed: 15.04.2020.

ORAM (Organization for Refuge, Asylum \& Migration). Blind alleys. The unseen struggles of lesbian, gay, bisexual, transgender and intersex urban refugees in Mexico, Uganda and South Africa. Part II. Country findings: South Africa. 2013. Available at: < https://oramrefugee.org/wp-content/uploads/2019/12/20130226oram_ba_southafrica.pdf $>$. Accessed: 15.04.2020.

PASSOP (LGBTI Refugee Support and Advocacy Project). A Dream deferred: is the Equality Clause in the South African Constitution's Bill of Rights (1996) just a faroff hope for LGBTI asylum seekers and refugees?. 2012. Available at: < https:// www.refworld.org/pdfid/4ffd29f92.pdf>. Accessed: 15.04.2020.

ROBERTS, Benjamin; REDDY, Vasu. Pride and prejudice: public attitudes toward homosexuality. 2008. Available at: <http://www.hsrc.ac.za/uploads/ pageContent/1607/Pride\%20and\%20Prejudice.pdf>. Accessed: 15.04.2020. 
THE YOGYAKARTA PRINCIPLES. Principles on the application of International Human Rights Law in relation to sexual orientation and gender identity. 2007. Available at: <http://yogyakartaprinciples.org/wp-content/uploads/2016/08/ principles_en.pdf $>$. Accessed: 15.04.2020.

UKLGIG (UK Lesbian \& Gay Immigration Group). Failing the grade: Home Office initial decisions on lesbian and gay claims for asylum. 2010. Available at: <https://uklgig.org.uk/wp-content/uploads/2014/04/Failing-the-Grade.pdf > . Accessed: 15.04.2020.

UKLGIG (UK Lesbian \& Gay Immigration Group). Missing the mark: decision making on lesbian, gay (bisexual, trans and intersex) asylum claims. 2013. Available at: <https://uklgig.org.uk/wp-content/uploads/2014/02/Missing-the-Mark.pdf > . Accessed: 15.04.2020.

UKLGIG (UK Lesbian \& Gay Immigration Group). Still falling short: the standard of Home Office decision-making in asylum claims based on sexual orientation and gender identity. 2018. Available at: <https://uklgig.org.uk/wp-content/ uploads/2018/07/Still-Falling-Short.pdf > . Accessed: 15.04.2020.

UNHCR (United Nations High Commissioner for Refugees). Guidelines on International Protection: gender-related persecution within the context of Article 1A(2) of the 1951 Convention and/or its 1967 Protocol relating to the Status of Refugees. 2002a. Available at: <https://www.unhcr.org/publications/ legal/3d58ddef4/guidelines-international-protection-1-gender-relatedpersecution-context.html>. Accessed: 15.04.2020.

UNHCR (United Nations High Commissioner for Refugees). Guidelines on International Protection: "membership of a particular social group" within the context of Article 1A(2) of the 1951 Convention and/or its 1967 Protocol relating to the Status of Refugees. 2002b. Available at: <https://www.unhcr. org/publications/legal/3d58de2da/guidelines-international-protection-2membership-particular-social-group.html>. Accessed: 15.04.2020.

UNHCR (United Nations High Commissioner for Refugees). Guidelines on International Protection no. 9: claims to refugee status based on sexual orientation and/or gender identity within the context of Article 1A(2) of the 1951 Convention and/or its 1967 Protocol relating to the Status of Refugees. 2012. Available at: $<$ https://www.unhcr.org/509136ca9.pdf > . Accessed: 15.04.2020.

UNHCR (United Nations High Commissioner for Refugees). Global Trends. Forced Displacement in 2017. 2018. Available at: <https://www.unhcr.org/ globaltrends2017/>. Accessed: 15.04.2020.

VIEIRA, Paulo. Mobilidades, migrações e orientações sexuais. Percursos em torno das fronteiras reais e imaginárias. Ex aequo, v. 24, p. 45-59, 2011.

WEßELS, Janna. HJ (Iran) and HT (Cameroon) - Reflections on a new test for sexuality-based asylum claims in Britain. International Journal of Refugee Law, v. 24, n. 4, p. 815-839, 2013. 